\title{
Tri Hita Karana: Subak Abian's Wisdom to Improve the Coffee Quality
}

\author{
A Wijaya \\ Department of Sociology and Anthropology, Universitas Negeri Semarang \\ \{atika.wijaya@mail.unnes.ac.id\}
}

\begin{abstract}
Subak Abian is a traditional farmer organization in Bali that adheres to the Hindu philosophy of "Tri Hita Karana", which translates as three causes of happiness that can be obtained when one has a good relationship with God, other people and nature. This philosophy itself is a starting point of Subak Abian to continue the tradition of coffee plantation in Bali in a sustainable way. However, the quality of its Arabica coffee is still low. Therefore, the local government engaged Subak Abian to improve the quality by establishing a processing unit with more advanced management that become an agribusiness of Kintamani coffee later. This study aims to analyse the transformation of Subak Abian from their traditional organization into an agribusiness unit that bring Kintamani coffee to the worldwide. In this matter, we try to describe the role of Subak Abian in improving the quality of sustainable coffee production by identifying their nature as social organization and its local values. This study employs qualitative approach and the data is collected through in-depth interviews with coffee farmers (Subak Abian members) and the local government officials, observation, and document analysis. This study is important and interesting for other regions to transform their local community-based organizations to contribute to the regional development.
\end{abstract}

Keywords: Coffee Farmers, Local Wisdom, Subak Abian, Sustainable Coffee Production.

\section{INTRODUCTION}

Bali is famously worldwide as the most popular tourists destination in Indonesia. Bali is also well-known as the land of Gods, in which Bali is gifted with its magnificent natural beauty of sandy beaches, mountains, and terraced rice paddy fields. Many international and domestic tourists spent their holiday in Bali. Therefore, regional development in Bali mostly influenced by its tourism sector. Nevertheless, together with tourism sector, agricultural sector is also important in supporting Bali's regional development. Bali is rich with tradition and embraced with religious norms, that made Bali has many local wisdom that still exist within the society. It can be said that agricultural system in Bali is very unique because it is enriched with indigenous values.

Agriculture in Indonesia existed even during kingdoms era and colonialism era, in which it contributed to the country's economy and its development [1]. The majority of Indonesian agriculture is staple food such as rice paddy, maize, soy, and cassava that important to domestic consumption. Meanwhile, coffee and spices have a long history in Indonesian plantation which brought by the Dutch colonial and they asked the local to plant it. Until today, those coffee 
plantation became the important export commodity which has high valued among others producers in the global market.

Agriculture knowledge system in Asia, including Indonesia, was built based from indigenous knowledge and experiences which inherited from generation to generation [2], [3]. In Java island, for example, traditional farmers has its own philosophical view and applied traditional seasonal rules (pranoto mongso) to know what to plant and when the right time to plant [1]. Another example is the use of calendar of Chinese 24 solar terms as an important lunisolar calendar in China. This calendar is based on farmers' observations of the position of the sun and the moon, and climate conditions [3]. Those local knowledge were very helpful for farmers to manage their farms since hundreds years ago even before agricultural technology developed. Therefore, it is interesting to know how local wisdom influenced the improvement of agricultural system in Indonesia.

Coffee is one of export commodity that contributed to Indonesian economy. However, the low quality due to improper on-farm management and post-harvest process have made the selling price is low [4], [5]. Coffee farmers in Indonesia are also lack of knowledge, capital, and technology so they manage the coffee farm traditionally [6]. All of these factors are made the coffee plantation sector in Indonesia is not well developed despite the prospective export value. In Bali, since 2001/2002, there is a program called Motramed (in English: Mediated Partnership Model) which targeted Subak Abian to change the way of farming and post-harvest to produce more quality coffee [7]. By encouraging local values and incorporated with traditionally social organization called Subak Abian, this program worked effectively in improving the quality and price of Arabica coffee in Kintamani, Bali.

This paper aims to describe the role of Subak Abian in improving the quality of Arabica coffee in a more sustainable way in Kintamani, Bali. We are particularly interested in the process of Subak Abian as a traditional social organization which adheres to local values being transformed into a processing unit and collective marketing actor of Kintamani Arabica coffee. First, we explain about local wisdom in agricultural sector, Next, we explain the research methods. Later, we analyze the role of Subak Abian in improving Arabica coffee quality in Kintamani through a partnership model. In the conclusion, we reflect on the findings.

Indonesia consists of many ethnics, culture and tradition that spread in various islands and regions. The tradition and indigenous knowledge created many local values or called as local wisdom. [8] expressed local wisdom as a thought of life. Moreover, [9] explained that local wisdom is forms of knowledge, beliefs, and ethics of human behaviour in the ecological community's lives. In agriculture, local wisdom can be viewed as a tradition that related with farming activities, livestock, building house, etc. [10]. Agriculture in Southeast Asia countries plays an important role in the life of people in rural society [11].

Modern development nowadays could not be separated with local values that passed down in the society from generation to generation. The government itself encouraged local values to be fitted with the regional development mainly on social aspect. The agricultural development in Indonesia cannot be separated from local wisdom. Bali people itself keep their wisdom by implementing Tri Hita Karana from Hinduism, where everyone need to keep harmonious relationship with others, environment (plant and animals), and God the Creator. Moreover, [10] mentioned that local wisdom is part of social capital that will be beneficial for the implementation of development program.

Traditional agricultural organizations, such as Subak Abian in Bali, contain local norms and network which based on trust among its members and actualize into moral behaviour [10]. Traditional institution in Bali are well maintained in order to conserve the environment. For example, farmers agreed not to use chemical inputs in their farm, so they plant and cultivate 
their farms organically. This value aims to protect the environment as part of their relation with people and environment (refer to Tri Hita Karana). This value is in accordance with the emergence of sustainable agriculture in the last decades. Sustainable agriculture becomes the trend in order to improve small-scale farmers' welfare by promoting organic agriculture to reach niche market [11].

In her research, [10] identifies some characters that contain in Balinese local wisdom. Gotong royong or mutually help in their daily activities such as rice field and plantation activities, ceremonies, repairing house, and celebration. Nyepi holy day, for example, is the time where Balinese stopped their activities for 24 hours doing nothing even turn on the light. Nyepi can be interpreted as opportunity for the nature to rest after fulfilled by pollution from human activities. Other ceremonies to thank the God about the animal and plant existence also exist in Bali. All of these ceremonies are maintained and contributed to the environmental conservation.

\section{RESEARCH METHOD}

\subsection{Research Location}

This research is located in Kintamani sub-district, Bangli district, Bali province. With the position about 1,500 metre above sea level, Kintamani is a highland area which is worldwide well-known as Arabica coffee producer and its magnificent view of volcano Mount Batur and Lake Batur. Kintamani in general still traditional and highly holds religious norms as home to Pura Ulun Danu Batur as one of Bali's key nine directional temples.

\subsection{Data Collection}

In this research, we employed three main data collection methods. First, semi-structured interviews were used to gain a comprehensive view on the role of Subak Abian in Kintamani in the improvement of coffee quality. The informants were chosen through purposive sampling by selecting representatives from four Subak Abian - Kertawaringin, Triguna Karya, Bhaktiyasa, and Ulian Murni. These four Subak Abian are the first initiator of using a new way of coffee processing with better quality. During the data collection process, we continuously crosschecked the information that we had previously obtained from the informants. Second, we analysed documents from the agriculture and plantation office of Kintamani sub-district, published articles and reports related to Subak Abian, the book of Kintamani Bali Geographical Indications, and statistical data of coffee production in Bali province and Bangli district. Third, we observed the activities of coffee farmers in Kintamani in the farm and the post-harvest process from their storage room until ready to sell.

\section{RESULT AND DISCUSSION}

\subsection{The Characteristics of Subak Abian}

Subak Abian is a traditional farmer organization that adheres to the Hindu philosophy of Tri Hita Karana, which means that there are three causes of happiness that can be obtained when one has a good relationship with God, people, and environment [6]. [12] elaborated the philosophy of Tri Hita Karana into the following. First, the relationship with God or parahyangan is actualized in the building of Pura Subak Abian as a ceremonial place. Second, the relationship with people or pawongan is actualized in monthly meeting and mutually help 
(gotong royong) among members of Subak Abian. Last, the relationship with environment or palemahan is actualized in the farming practices in a sustainable way. Tri Hita Karana is the way of life Balinese farmers which become a beneficial point that contributed to the implementation program of the improvement Arabica coffee in Kintamani, Bangli, Bali. Coffee farmers in Kintamani which already well organized into Subak Abian for a long time, keep this tradition in their on-farm management.

Subak has functions to manage irrigation and land for paddy rice, and the executor of ritual activities [13]. More explanation about Subak Abian explained by the researcher of ICCRI and the initiator of Motramed as follows:

"Subak is an old tradition of agricultural system in Bali. Subak comes from Bali local language "se uwa" which means one area that can be fed by a spring. Abian is dry land. So, Subak Abian is a agricultural system for dry land. This system in 1980s adopted by the national government. Usually each Subak Abian consists of 30-40 household."

Subak Abian refers to the traditional organization of farming that based on a region on how far can be reach by spring. Moreover, Subak Abian aims to improve economic system based on subak system in Bali.

The inter-connected relationship between farmers, their God, other people and environment are internalized in their farming practices. Not only focused on their farm management, but they also held religious ceremonial event regularly as their sign of gratitude to their God. Moreover, the relationship towards other people actualized in their social value. The social value of Subak Abian that is mutually help (gotong royong) has encouraged them to establish a larger organization to achieve bigger goal. For instance, their achievement in Geographical Indication (GI) for Kintamani Arabica Coffee. Last, coffee farmers practiced what the modern people called organic. Coffee farmers in Kintamani never use the chemical inputs as this a sign of good relationship with environment. They believed that putting too much chemical inputs will only make damaged to the soil and it can be resulted in unsustainable plantation in the future.

The Community of Geographical Indication Protection (CGIP) Kintamani, which established in 2005, aims to assist the process of obtaining a Geographical Indication (GI) certificate. CGIP plays role as a supervisor of the quality of Bali Kintamani Arabica coffee. The member of CGIP consists of 61 Subak Abian, 6 local coffee processors with wet processing technique, the local governments, ICCRI, and companies as an advisory board [14]. In addition to that, in 2008, Kintamani Bali Arabica Coffee was awarded a Geographical Indication certificate. This GI certificate is the first in Indonesia and hold by the community of Kintamani. The strong bound of Subak Abian is possible to work together and maintaining the strong relationship in keeping the Arabica coffee tradition in Kintamani into global market.

\subsection{The Improvement of Arabica Coffee Quality}

Coffee is an important commodity for national economy and Indonesia is the big five coffee producer in the world. Not only contributed to the national export value, but also as a source of household income for millions of farmers. Indonesian Arabica coffee is well known with its specialty characteristics. Moreover, Arabica the coffee price at the global market and domestic market is increasing day by day due to high demand. Therefore, it becomes a market opportunity for coffee producer in Indonesia to expand their market.

Kintamani Arabica coffee has a long history and well known as a specialty coffee with its unique flavour and scent. However, there are major problems on Kintamani Arabica coffee that 
might hinder the export to various countries. First, low quality of coffee beans which caused by improper on-farm management and poorly post-harvest process. Second, long supply chain from farmers to consumers that makes farmers only received low prices. Arabica coffee even has lower in price compare to Robusta coffee in Kintamani. This condition led to the lost motivation of coffee farmers and preferred to change to tangerine plants or others plants that give more profit.

Therefore, the province government of Bali and the district government of Bangli, where Kintamani is located, in collaboration with ICCRI (the Indonesian Coffee and Cocoa Research Institute) initiated a program called Motramed (in English: Mediated Partnerhsip Model). Motramed aims to improve coffee quality and shortening the marketing channel in order to improve farmers' welfare [6]. Through this program, farmers learn how to improve the coffee quality by applying new processing method that enhanced the taste of coffee. ICCRI as the initiator of this partnership played a role as a knowledge provider regarding the quality assurance and disseminated the knowledge to the governmental staffs and farmers. This program was started in 2001/2002 with four subak abian. The role of provincial government is facility support such as machines and funds. More about this program and its involved actors explained as follows:

"Motramed is a partnership program between ICCRI, the local government, and coffee farmers. We have the idea then we develop it. This program is an alternative way to educate farmers. Our program is based on education not regulation. In Bali, only the provincial government that welcome and support our ideas. Meanwhile, the district government was not actively support in the implementation." (Interview with ICCRI's researcher and Motramed's initiator).

The target of this program is Arabica coffee farmers in Kintamani. The first Subak Abian that joined Motramed is Kertawaringin, then followed by other three Subak Abian; Tri Guna Karya, Alian Murni, and Bhaktiyasa. At first, it was not easy to ask farmers to participate in the partnership. Traditional farmers tend to decline the change and hesitant to learn something new. Therefore, this selection based on the their motivation, the one who ready and has high motivation. It means they are willing to learn and change the traditional way of coffee processing. Farmers were more attracted to the economic advantages than the environmental protection or the health safety.

In Motramed program, the government support Subak Abian by establishing a processing unit and providing machines. The implementation of this partnership in Kintamani benefited from the existence of Subak Abian. In other regions, Java for example, the governments and ICCRI have to form farmer organizations first before launched the programs. However, in Kintamani, Subak Abian is already well established as social organizations related to farming activities. Therefore, the governments and ICCRI are easier to implement the program as they only selected the four subak abian as the pioneer of the partnership program. These farmers were thought how to comply the standard operating procedures (SOP) of post-harvest coffee.

In the collaboration or partnership, each involved partner should have common problems in which through this collaboration they could find advantages and benefit. If farmers interested in increasing their income, then the local governments interested in improving regional economy. Therefore, after their hard work coffee farmers could produce better quality by applying new technique. Consequently, the price is also increase (see Fig. 1) 


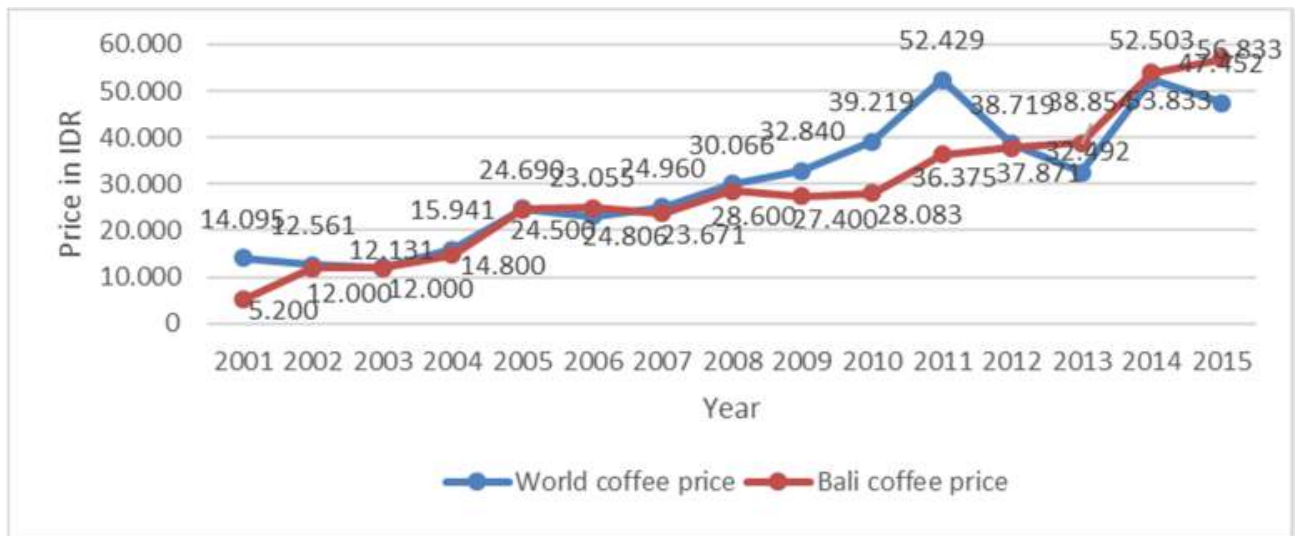

Figure 1. The price of Bali coffee compared with the world coffee price [8].

The figure shows that in the last decade from 2001 until 2015 there was a significant increase of coffee price in Bali compare to before the implementation of Motramed in 2001. The increased in coffee price attracted and encouraged more Subak Abian to participate in the collaborative program. After only focus on four Subak Abian which mentioned earlier, the local governments and ICCRI added four Subak Abian each year for receiving training and facility support.

\section{CONCLUSIONS}

The coffee farmers in Kintamani faced some difficulties regarding the quality of their Arabica coffee. Low quality of coffee due to improper management on-farm and post-harvest processing is resulted in low price. Meanwhile, the farmers itself have limited knowledge on how to improve the quality of Arabica coffee. However, the existence of Subak Abian as a traditional organization on farming activities encouraged the success of collaborative partnership between ICCRI, the local governments, and farmers. Local values that adhere by Subak Abian worked in two aspects. First, sustaining the environmental or palemahan is actualized by Subak Abian in the way of farming practices by not using chemical inputs or called as organic farming. Moreover, there is a way to keep environment is balanced by not doing any activities in the farm on holy days such as Nyepi. Instead they make ceremony and pray in Pura. Second, Subak Abian becomes an economy unit of coffee processing and collective marketing. The value of mutually help encouraged coffee farmers to improve coffee quality to get higher price. After the success of Motramed, nowadays, Kintamani Bali Arabica coffee is well developed, higher quality and many global exporters come to Bali to buy Kintamani Arabica coffee directly from farmers organization.

\section{REFERENCES}

[1] A. S. Arif, "The Real Subak - Integrated Organic Farming as Tri Hita Karana Manifesto," in Bali ACLA 2015 International Symposium: Agricultural Landscape of Asia: learning, preserving, and redefining, no. 5, pp. 1-11, 2005.

[2] J. S. Ho and E. R. Gamarra, "A Story of Globally Important Agricultural Wisdom in the 15th Century Chos ŏ n Korea," Anthropology, vol. 6, no. 2, 2018.

[3] J. Wang, "Integrating Indigenous with Scientific Knowledge for the Development of 
Sustainable Agriculture: Studies in Shaanxi Province," Asian J. Agric. Dev., vol. 15, no. 2, pp. 41-58, 2018.

[4] J. Neilson, "Global private regulation and value-chain restructuring in Indonesian smallholder coffee system," World Dev., vol. 36, no. 9, pp. 1607-1622, 2008.

[5] E. S. Astuti, A. Offermans, R. Kemp, and R. Cörvers, "The Impact of Coffee Certification on the Economic Performance of Indonesian Actors," Asian J. Agric. Dev., vol. 12, no. 2, pp. 1-14, 2016.

[6] A. Wijaya, P. Glasbergen, and S. Mawardi, "The mediated partnership model for sustainable coffee production: Experiences from Indonesia," Int. Food Agribus. Manag. Rev., vol. 20, no. 5, 2017.

[7] S. Mawardi, C. Ismayadi, A. Wibawa, Sulistyowati, and Yusianto, "Model kemitraan bermediasi (MOTRAMED) untuk pengembangan agribisnis kopi melalui perbaikan mutu dan sistem pemasaran di tingkat kelompok tani," in Simposium Kopi, 2006.

[8] N. K. Karyati and N. W. Suryathi, "Implementasi Kearifan Lokal Tri Hita Karana dalam Menjaga Keberlanjutan Pertanian Kopi Pada Subak Abian Tri Guna Karya Kintamani Bangli," dwijenAGRO, vol. 8, no. 1, pp. 147-159, 2018.

[9] S. Keraf, Etika Lingkungan. Jakarta: Penerbit Buku Kompas, 2002.

[10] N. U. Vipriyanti, "Banjar Adat and Local Wisdom : Community Management For Public Space Sustainability in Bali Province," in IASC 12th Bienniel Conference, pp. 1-7, 2008.

[11] T. Jitsanguan, "Sustainable Agricultural System for Small-Scale Farmers in Thailand: Implications for the Environment," Food Fertil. Technol. Cent. Asian Pacific Reg., pp. 1$11,2001$.

[12] D. Lestari, "Peranan Subak Abian dalam Rangka Peningkatan Kualitas Kopi Arabika Kintamani Bali Tahun 2002-2008," Universitas Jember, 2015.

[13] I. Lanya, N. Subadiyasa, K. Sardiana, and G. P. Ratna Adi, "Planning of Agro-Tourism Development, Specific Location in Green Open Space Sarbagita Area , Bali Province," IOP Conf. Ser. Earth Environ. Sci., vol. 123, 2018.

[14] C. of G. I. P. of B. K. A. Coffee, "The Requirements Book of Geographical Indication," Bali, 2007. 